\title{
Corpus-Based Speech Act Analysis on the Use of Word 'Lu' in Cyber Bullying Speech
}

\author{
Devi Ambarwati Puspitasari \\ \{devi.ambarwati@kemdikbud.go.id\}
}

Badan Pengembangan dan Pembinaan Bahasa, Kementerian Pendidikan dan Kebudayaan

\begin{abstract}
The purpose of this study was to determine the discursive representation of the word " $l u$ " (you) in written speech on social media that has the potential to express cyber bullying. This research applied the methodology synergy of linguistic corpus and illocutionary speech act analysis. The data in this study included two corpus of cyber bullying taken from stories on several student community accounts on Twitter, Instagram, and Facebook in different periods (2012 and 2020). Analysis on words list and collocation was used to see patterns of using the word " $l u$ " in expressing cyber bullying. Furthermore, concordance was used to deepen the analysis of speech acts and to see the data qualitatively. Based on the results of the corpus analysis, 48 patterns of use of the word "lu" were found. Based on the data analysis from the perspective of speech acts, there were five types of speech acts that appear and were dominated by assertive speech in the form of statements containing taunts and negative nicknames.
\end{abstract}

Keywords: linguistic corpus, cyber bullying, social media.

\author{
Analisis Tindak Tutur Berbasis Korpus pada Penggunaan Kata 'Lu' \\ dalam Tuturan Perundungan Siber
}

\begin{abstract}
Abstrak. Tujuan penelitian ini adalah untuk mengetahui representasi diskursif kata "lu" pada tuturan tertulis di media sosial yang berpotensi mengekspresikan perundungan siber. Penelitian ini menerapkan sinergi metodologi korpus linguistik dan analisis tindak tutur ilokusi. Data dalam penelitian ini mencakup dua buah korpus perundungan siber yang diambil dari tuturan di beberapa akun komunitas pelajar di Twitter, Instagram, dan Facebook pada periode berbeda (tahun 2012 dan 2020). Analisis pada daftar kata dan kolokasi digunakan untuk melihat pola penggunaan kata "lu" dalam mengekspresikan perundungan siber. Selanjutnya, konkordans digunakan untuk memperdalam analisis tindak tutur dan melihat data secara kualitatif. Berdasarkan hasil analisis korpus, telah ditemukan 48 pola penggunaan kata "lu." Berdasarkan analisis data dalam sudut pandang tindak tutur, ada lima jenis tindak tutur yang muncul dan didominasi oleh tuturan asertif berupa pernyataan yang berisi ejekan dan julukan negatif.
\end{abstract}

Kata kunci: korpus linguistik, perundungan siber, media sosial. 


\section{Pendahuluan}

Derasnya arus komunikasi masyarakat dunia melalui media sosial, khususnya pada dekade terakhir ini, membawa sebuah dampak besar pada munculnya varian-varian bahasa. Semua pengguna media sosial secara tidak langsung mendorong pemakaian sebuah bahasa yang dapat dipahami bersama. Fenomena pemakaian bahasa di media sosial ini di beberapa penelitian disebut sebagai "bahasa gaul" atau "bahasa medsos" [1].

Bahasa gaul atau bahasa medsos tentu tidak dapat disejajarkan dengan bahasa yang sudah ada dan dipakai di seluruh dunia. Bahasa medsos bukanlah suatu bahasa yang lahir diikuti oleh peristiwa sejarah dan perkembangan linguistiknya seperti bahasa-bahasa negara, bahasa internasional, ataupun bahasa daerah. Namun, semua orang terpaksa mengakui bahwa bahasa medsos itu ada dan dipakai. Dalam pemakaiannya, bahasa medsos mencakup semua bahasa yang dipakai atau setidaknya dipahami oleh pengguna media sosial [2]. Contohnya di dalam satu kolom komentar dapat ditemukan percampuran lebih dari satu bahasa yang sangat kompleks, namun sangat mudah dimengerti oleh para pengguna media sosial.

Beberapa ahli bahasa tidak bersepakat menyebut fenomena dalam komunikasi media sosial tersebut sebagai "bahasa" media sosial. Penyebutan bahasa medsos dianggap terlalu dini untuk sebuah bahasa yang lahir dari percampuran berbagai bahasa yang diakui. Maka sebagian besar ahli bahasa menyebutnya sebagai "ragam" bahasa di media sosial [2]. Pemakaian kata "ragam" dianggap lebih tepat, karena ragam bahasa adalah variasi bahasa menurut pemakaian, topik pembicaraan, hubungan pembicara, lawan bicara, orang yang dibicarakan, serta medium pembicaraan yang sudah sangat mengerucut yaitu media sosial [3].

Fenomena tindak tutur di media sosial ini banyak membawa pengaruh bagi masyarakat. Tuturan-tuturan media sosial memiliki kekuatan yang sama seperti tuturan-tuturan langsung didunia nyata, baik positif maupun negatif. Sebagian tuturan di media sosial mampu membawa keterpurukan dan pengaruh negatif bagi sebagian orang, bahkan tidak jarang berakhir di ranah hukum. Salah satu contohnya tuturan yang membawa dampak hukum adalah tuturan perundungan siber [5], [6], [7].

Penelitian perundungan siber sering dilakukan dengan pendekatan psikologi dan sosial [10], [11], komunikasi [12], [13] dan forensik digital [14], [16]. Penelitian-penelitian tersebut tidak fokus melihat perundungan siber dari sisi kebahasaan. Dengan demikian, belum ada penelitian yang melakukan telaah alat bukti kebahasaan dalam kasus perundungan siber dengan pendekatan linguistik.

Pendekatan linguistik terhadap data-data media sosial yang sering digunakan adalah pendekatan Pragmatik, khususnya tindak tutur [8]. Namun, data media sosial yang cenderung besar, membutuhkan pendekatan lain untuk memunculkan generalisasi yang lebih akurat, seperti korpus linguistik. Penelitian menggunakan korpus linguistik telah banyak digunakan untuk mendapatkan gambaran global yang lebih detail terhadap data kebahasaan [17].

Korpus linguistik telah banyak digunakan dalam penelitian pembelajaran bahasa asing, seperti bahasa Arab [18] dan bahasa Inggris [19]. Kedua penelitian tersebut bertujuan untuk mengetahui sudah sejauh mana dan sudah seluas apa pembelajaran bahasa asing di Indonesia. Kedua juga menyimpulkan bahwa korpus linguistik dapat dipakai untuk membuat peta penguasaan bahasa asing.

Penelitian korpus linguistik lainnya yang melatarbelakangi penelitian ini adalah penelitian tentang pemakaian sinonim dalam bahasa Inggris. Hasil penelitian tersebut menunjukkan bahwa korpus linguistik mampu memberikan data daftar kata, kolokat, dan konkordan secara terperinci [19]. Umumnya penelitian yang memanfaatkan korpus linguistik digunakan untuk 
menganalisis teks-teks dengan tema tertentu dan menggunakan teori analisi wacana kritis [20]. Namun tidak banyak penelitian yang mengolah data tuturan menjadi sebuah korpus linguistik [21]. Hal tersebut dikarenakan sebuah tuturan umumnya tidak dituliskan, sehingga dalam penggunaannya perlu melalui tahap transkripsi.

Berbeda dengan penelitian-penelitian linguistik korpus yang sebelumnya telah dilakukan, dimana umumnya memanfaatkan teks-teks baku, seperti buku, koran, atau hasil tulisan pembelajar bahasa asing, penelitian ini menggunakan data tuturan dari media sosial. Penelitian ini berupaya menganalisis data tuturan yang nyata digunakan oleh masyarakat Indonesia dengan memanfaatkan piranti korpus linguistik.

Dengan tanpa melihat motif tuturan dan jarak sosial para pelajar tersebut, penelitian ini bertujuan untuk mengetahui representasi diskursif kata "lu" pada tuturan tertulis di media sosial yang berpotensi mengekspresikan perundungan siber dengan menerapkan sinergi metodologi korpus linguistik dan analisis tindak tutur ilokusi. Pemilihan kata "lu" sebagai pusat pencarian data didasarkan pada hasil pengolahan korpus perundungan siber yang menyebutkan kata "lu" sebagai kata yang paling tinggi frekuensi pemakaiannya dalam tuturan perundungan siber. Oleh karena itu, perlu diketahui pola penggunaan kata "lu" dalam mengekspresikan perundungan siber dan jenis tindak tutur yang muncul, serta dominasi tuturannya. Penelitian ini menggunakan dua buah korpus perundungan siber pada periode berbeda, yaitu data tuturan perundungan siber tahun 2012 dan tahun 2020. Penggunaan dua buah korpus pada periode yang berbeda bertujuan untuk memberikan gambaran perbedaan ragam bahasa di media sosial pada tahun 2020 dan delapan tahun silam.

Penelitian ini mengacu pada gagasan Austin [22] dan Searle [23] mengenai teori tindak tutur (Speech Act Theory) dan gagasan Herring [24] tentang komunikasi daring. Teori tindak tutur merupakan taksonomi praktis yang telah digunakan dalam studi pemrosesan bahasa alami dan komunikasi dimediasi komputer [25]. Selanjutnya, teori tindak tutur memungkinkan peneliti untuk menjelaskan makna yang dimaksudkan dari pesan yang diidentifikasi dan dikodekan sebagai tindakan ilokusi.

Setelah mengklasifikasikan ujaran menjadi performatif dan konstatif, serta membagi tindak tutur menjadi tindakan lokusi, ilokusi, dan perlokusi. Konsep dan taksonominya diperluas oleh Searle [23], yang mengusulkan aturan konstitutif dan memperluas gagasan Austin tentang penyerapan dengan menyatakan bahwa kinerja tuturan melibatkan tindakan penuturnya. Dengan mengembangkan karya Austin, Searle memperkenalkan perbedaan antara arti kata atau kalimat literal dan makna ucapan pembicara. Bagi Searle, produksi sebuah kata atau kalimat dalam tindak tutur merupakan unit dasar informasi linguistik. Selanjutnya ia membagi tuturan ilokusi menjadi lima kategori, yaitu asertif, direktif, komisif, ekspresif, dan deklaratif [26].

\section{Metode}

Penelitian ini adalah penelitian kualitatif dengan melibatkan peneliti sebagai instrumen penelitian dan memanfaatkan pangkalan data Laboratorium Forensik Kebahasaan (Pusat Pengembangan dan Pelindungan Bahasa dan Sastra, Badan Pengembangan dan Pembinaan Bahasa, Kemendikbud). Data dalam penelitian ini adalah dua buah korpus perundungan siber yang diolah menggunakan aplikasi Korpus Forensik Kebahasaan (Korpus Forbas). Dua korpus perundungan siber yang diambil dari aplikasi Korpus Forbas tersebut terdiri dari tuturan di 
sejumlah akun komunitas pelajar di Twitter, Instagram, dan Facebook pada periode berbeda, yaitu tahun 2012 dan 2020.

Jumlah keseluruhan data adalah 4.586 tuturan yang mencakup 13.063 kata. Daftar kata yang dipilih pada hasil pengolahan korpus adalah kata "lu" dan kolokasi yang dipilih adalah R1 (satu kanan) dan L1 (satu kiri). Langkah-langkah analisis data dalam penelitian ini adalah reduksi data, tabulasi data, penyajian data, triangulasi data, dan penarikan kesimpulan. Triangulasi data dalam penelitian ini dilakukan melalui pengecekan derajat kepercayaan penemuan hasil penelitian melalui diskusi.

\section{Hasil dan Pembahasan}

\subsection{Pola Penggunaan Kata "lu"}

Berdasarkan data frekuensi korpus perundungan siber, kata "lu"menempati ranking pertama. Pada data periode tahun 2012 (A12), kata "lu" dipakai sebanyak 108 kali dari 1.631 daftar kata yang muncul. Sedangkan pada data period 2020 (A20), kata "lu" dipakai sebanyak 463 kali dari 2.955 daftar kata yang muncul. Meskipun pada A20 kata "lu"memiliki frekuensi lebih banyak dari pada A12, keduanya memiliki kecenderungan yang sama. Hal tersebut terbukti dari hasil analisis kolokat pada tetangga kanan (R1) dan tetangga kiri (L2). Hasil analisis kolat menunjukkan adanya kecenderungan pada pola struktur pemakaian kata "lu". Berikut adalah tabel pola struktur yang paling sering digunakan untuk kata "lu".

Tabel 1. Pola Struktur Pemakaian Kata "lu"

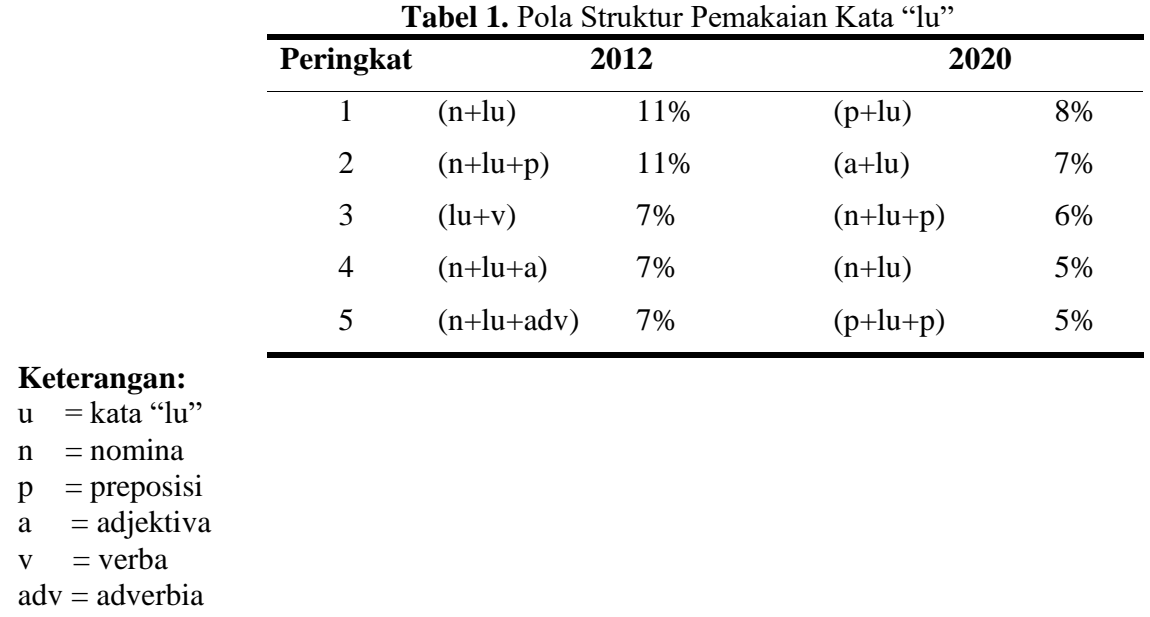

Tabel 2. Pola (n+lu) pada A12

\begin{tabular}{l|rrrr}
\hline A12.01 & Mending tangan kosong! BANCI & $L$ & !! ah bacot lu..gw sumpain lu org \\
& & $u$ & \\
A12.02 & juga ga da tbtb ngmg gemukan. Babi & $L$ & !!! Aku setuju. Melayu memang pemalasa \\
& & $u$ & \\
A12.27 & KEBANYAKAN MINUM KECING & $L$ & !!! gua selalu kesel banget sama orang yg \\
& ONTA & $U$ & \\
A12.28 & kelakukan setan kura, dasar anak setan & $l u$ & !!! Gua mah terserah lu
\end{tabular}


A12.31

A12. 46

A12.49
BANCI lu !! ah bacot lu .. gw sumpain lu org yg bunuh di

Anak pelacur lu , lahir dari ibu lonte ya gini otak

Ckck otak lu yang lari dari kepala lu ! Lu jelek, makanya lu foto nutupin muka

Dari sisi tetangga kiri (L1), pola (n+lu) pada A12 muncul dengan diakhiri dengan tanda baca, yaitu satu atau beberapa tanda seru (!), satu atau beberapa tanda titik (.), satu atau beberapa tanda tanya (?), dan satu atau beberapa tanda koma (,). Tanda baca tersebut berfungsi sebagai penekanan terhadap tuturan yang diungkapkan.

Materi yang diunggah melalui teknologi elektronik ini bersifat agresif dan melukai sehingga dapat mengakibatkan ketidaknyamanan baik fisik maupun psikis bagi orang lain [11]. Materi-materi tersebut terlihat pada pola $(n+l u)$, dengan munculnya daftar kata benda yang bermakna negatif, baik secara harfiah maupun asosiatif. Berikut adalah daftar kata pada R1 dan daftar tanda baca pada L1 dari data A12 yang muncul pada pola (n+lu).

Tabel 3. Daftar Kata R1 dan L1 dari Data A12 pada Pola (n+lu).

\begin{tabular}{rl}
\hline $\mathbf{R 1}$ & $\mathbf{L 1}$ \\
\hline anjeeeeeng, anjeng, anjing, anjink, & $(!),(! !),(! ! !),(! ! ! !),(! ! ! ! ! !),(),.(.)$, \\
babi, bacot, banci, bibir, cewe, & $(\ldots),(\ldots),(\ldots .),.(\ldots),(),,(),,(,)$, \\
cowo, cwek, cwo, kepala, laki, lakik, & $(,,),,(,,,,),,(?),(? ?),(? ? ?)$ \\
laler, lonte, mata, onta, pelacur, \\
perbuatan, setan
\end{tabular}

Pola $(\mathrm{n}+\mathrm{lu})$ pada A12 juga tampak pada A20, meskipun tidak pada urutan pertama atau hanya berjumlah 5\% dari keseluruhan data. Dari analisis R1, tuturan perundungan siber juga banyak diekspresikan menggunakan kata benda sebagai representasi objek perundungan. Nomina yang sering dipakai adalah nama-nama binatang, anggota tubuh, dan kata benda lainnya yang memiliki makna negatif. Nomina dengan kategori-kategori tersebut adalah nomina yang sering dipakai untuk melukai objek atau sasaran perundungan [8]. Terdapat sebuah kecenderungan daftar kata benda tertentu yang sering muncul dalam tuturan perundungan siber yang tampak pada data A20. Berikut adalah beberapa contoh pola $(n+l u)$ pada A20.

Tabel 4. Contoh Pola $(\mathrm{n}+\mathrm{lu})$ pada A20

\begin{tabular}{|c|c|c|}
\hline A20.01 & gapunya kaca. Pantes ga ounya etika! bacot lu & .... galih lu ngehina anakl kelas \\
\hline A20.10 & dasar anak dakjal lu & !!! "Anjing setan, ga pantes pake nama \\
\hline A20.85 & aja belagu! Cih! Ngaca pake sempak bapa lu & ! Dasar dekil! Dekil aja belagu, sok \\
\hline A20.108 & di kira bagus mamerin harta ortu lu & ? Eh ketek kadal yang punya harta tuh \\
\hline A20.109 & ada loh ... Manteb juga mobil sama jam & , eh maksud gua HARTA ORTU LU yeee kan \\
\hline A20.110 & PEREBUT PACAR ORANG LU & !! EH SI ANJING, PERLY GUE BEBER \\
\hline A20.293 & boss beraninya di dumai gapunya nyali lu & $\begin{array}{l}\text { ????najong. Lagian juga ngaca dong, lu } \\
\text { item }\end{array}$ \\
\hline A20.294 & kadal gurun kbykan minum kencing onta lu & , nalar lu kebolak balik "maaf ni mba \\
\hline A20.394 & ..... songong lulus snmptn: Kontol & . Songong! Tai! Oh jadi ini hasil \\
\hline
\end{tabular}


Nomina pada A.20 lebih bervariasi dibandingkan dengan A.12 dan memunculkan tren baru yang tidak muncul di tahun 2012. Salah satu contohnya adalah kata "dakjal" yang merupakan bentuk tidak baku dari kata "dajal". Berikut adalah daftar kata R1 dan L1 dari data A12 yang muncul pada pola $(n+l u)$.

Tabel 5. Daftar Kata R1 dan L1 dari Data A20 pada Pola (n+lu)

\begin{tabular}{rc}
\hline $\mathbf{R 1}$ & $\mathbf{L 1}$ \\
\hline etika, dakjal, ortu, bapa, bapak, emak, mak, & $(!),(! !),(! ! !),(! ! ! !),(! ! ! ! ! !),(),.(.),.(\ldots),(\ldots)$, \\
bangsat, bangsad, jam, orang, ginjal, cowok, & $(\ldots .),.(\ldots),.(),,(),,(,,),,(,,),,(,,,,),,(?),(? ?)$, \\
cwo, cowo, cewek, cewe, cwe, twins, pacar, & $(? ? ?)$ \\
nyali, onta, bacot, kontol, kntol, memek, meki, & \\
mekki, jidad, bibir, mata, perut, kulit, rambut, & \\
otak & \\
\hline
\end{tabular}

Mengenai daftar kata L1 pada A20, pola tanda baca pada $(n+l u)$ masih memiliki kecenderungan yang sama, yaitu satu atau beberapa tanda seru (!), satu atau beberapa tanda titik (.), satu atau beberapa tanda tanya (?), dan satu atau beberapa tanda koma (,). Pemakaian tanda baca secara berlebih merupakan ekspresi lebih yang diberikan penutur terhadap objek perundungan. Penggunaan tanda baca lebih dari satu menandakan salah satu bentuk materi agresif terhadap korban perundungan, sekaligus bentuk kebebasan dari pelaku perundungan.

Selain pola $(n+l u)$, pola $(n+l u+p)$ juga ditemukan di kedua data dan keduanya memperoleh persentase yang tinggi. Penggunaan preposisi setelah kata lu menjadi dominasi di antara keduanya dengan komposisi penggunaan kata benda pada R1 yang tidak jauh berbeda dengan pola $(n+l u)$. Berikut adalah beberapa contoh tuturan yang menggunakan pola $(n+l u+p)$.

Tabel 6. Contoh Tuturan yang Menggunakan Pola $(\mathrm{n}+\mathrm{lu}+\mathrm{p})$ pada $\mathrm{A} 12$

\begin{tabular}{|c|c|c|}
\hline A12.17 & $\begin{array}{r}\text { jadi MANUK SIA.. Tuhan udah nutupin } \\
\text { aib }\end{array}$ & $\begin{array}{l}\text { lu dgn sempurna, eh dgn gampangnya lu } \\
\text { sebar }\end{array}$ \\
\hline A12.18 & itu bukan perjuangan gobelok, otak & $\begin{array}{l}\text { lu dimana dulu pm terkenal dengan } \\
\text { anggota rohis }\end{array}$ \\
\hline A12.40 & $\begin{array}{r}\text { aja Gausah jadi manusia deh kalo } \\
\text { kelakukan }\end{array}$ & lu kyak Anjing! \\
\hline A12.42 & Sok seksi. Jablay 27. Lu tau tai? MUKE & $\begin{array}{l}\text { LU KAYA TAI! Gue sumpahin ya punya } \\
\text { anak }\end{array}$ \\
\hline A12.85 & Muka aja diasah ampe glowing, otak & lu tuh asah biar pinteran dikit, tolol kok \\
\hline
\end{tabular}

Penggunaan preposisi pada A12, khususnya pada pola $(n+l u+p)$ didominasi pemakaian kata "kayak" yang merupakan bentuk tidak baku dari kata "seperti". Hal tersebut berulang di tahun 2020, karena penggunaannya masih mendominasi. Namun yang berbeda adalah tingginya frekuensi penggunaan kata "kek" yang berupakan bentuk laian dari kata "kayak", baik pada pola $(n+l u+p)$, maupun pada pola lain yang mengandung preposisi seperti $(p+l u)$ dan $(\mathrm{p}+\mathrm{lu}+\mathrm{p})$. Kata "kek" sendiri ada pada peringkat ke-19 dari 2.995 tipe kata yang muncul pada A20. Sedangkan preposisi yang paling tinggi peringkatnya adalah kata "yg" (singkatan dari kata "yang"), yaitu ada di peringkat ke-3 setelah kata "lu" dan "aja". Namun kata "yg" umumnya digunakan untuk menghubungkan kalimat yang umumnya Panjang. Berbeda 
dengan kata "kek" yang cenderung disandingkan dengan kata "lu" sebagai penekanan ekspresi perundungan antara kata benda yang dirujuk dengan objek perundungan.

\subsection{Pemakaian Varian Kata dengan Makna Sama}

Berdasarkan analisis kolokat R1 dan L1, ditemukan 33 pola pemakain kata lu di A12 dan 48 pola di A.20. Analisis kolokat juga menunjukkan perbedaan kecenderungan pemakaian kata pada R1 dan L1. Selain "dakjal" versus "setan" dan "kya" versus kek", ditemukan pula kecenderungan pemakaian kata-kata lain dengan makna yang sama. Salah satu contohnya dapat dilihat dari kolokat R1 kata "anjing" pada pola $(\mathrm{n}+\mathrm{lu})$. Munculnya berbagai variasi dari suatu kata juga muncul pada nomina lain yang ditulis menyertai kata lu. Perbedaan kecenderungan pemakaian suatu variasi kata tahun 2012 dengan tahun 2020 dapat disimpulkan setidaknya dalam tiga kategori, yaitu nama binatang, anggota tubuh, kata benda populer. Ekspresi perundungan, baik pada A12 dan A20, didominasi menyebutkan kata benda sebelum kata "lu". Kata benda yang dirujuk digunakan sebagai representasi objek perundungan. Fakta menarik lainnya adalah tidak ditemukannya varian beberapa kata yang bermakna sama di kedua korpus tersebut pada pola $(n+l u)$ dan $(n+l u+p)$. Berikut adalah rangkuman daftar kata tersebut.

Tabel 9. Daftar Nomina pada Pola $(\mathrm{n}+\mathrm{lu})$ yang Bermakna Sama

\begin{tabular}{llll}
\hline Kategori & Daftar Kata & A12 & A20 \\
\hline nama binatang & anjing & $\sqrt{ }$ & \\
& anjay & $\mathrm{x}$ & $\sqrt{ }$ \\
anggota tubuh & kontol & $\sqrt{ }$ & $\sqrt{ }$ \\
& kimak & $\mathrm{x}$ & $\sqrt{ }$ \\
& muka & $\sqrt{ }$ & $\sqrt{ }$ \\
kata benda populer & komuk & $\mathrm{x}$ & $\sqrt{ }$ \\
lainnya & dakjal & $\sqrt{ }$ & $\sqrt{ }$ \\
& (perebut pacar) orang & $\mathrm{V}$ & $\mathrm{V}$ \\
& Pelakor & $\mathrm{x}$ & $\sqrt{ }$ \\
& pelacur & $\sqrt{ }$ & $\mathrm{x}$ \\
& lonte & $\mathrm{x}$ & $\sqrt{ }$ \\
& alay & $\sqrt{ }$ & $\sqrt{ }$ \\
& jamet & $\mathrm{x}$ & $\sqrt{ }$ \\
\hline
\end{tabular}

Tabel 10. Daftar Kata Populer yang Bermakna Sama

\begin{tabular}{lll}
\hline Daftar Kata & A12 & A20 \\
\hline ngarep $(\mathrm{v})$ & $\sqrt{ }$ & $\sqrt{ }$ \\
modus $(\mathrm{n})$ & $\mathrm{X}$ & $\sqrt{ }$ \\
ancur $(\mathrm{a})$ & $\sqrt{ }$ & $\sqrt{ }$ \\
ambyar $(\mathrm{a})$ & $\mathrm{X}$ & $\sqrt{ }$ \\
bohong $(\mathrm{v})$ & $\sqrt{ }$ & $\sqrt{ }$ \\
bokis $(\mathrm{v}) / \operatorname{modus}(\mathrm{n})$ & $\mathrm{X}$ & $\sqrt{ }$ \\
mbak, mas, bro / sis $(\mathrm{n})$ & $\sqrt{ }$ & $\sqrt{ }$ \\
bray/hyung/nder $(\mathrm{n})$ & $\mathrm{X}$ & $\sqrt{ }$ \\
\hline
\end{tabular}


Dua tabel di atas menunjukkan adanya perubahan kebiasaan dalam menggunakan kata atau istilah di sosial media. Baik untuk mengekspresikan tuturan yang bersifat netral ataupun apresiasi, baik apresiasi positif, mapupun negatif seperti perundungan siber.

\subsection{Hakikat Tujuan Pertuturan (illocutionary intention)}

Berdasarkan analisis data dalam sudut pandang tindak tutur, ditemukan ada lima jenis tindak tutur yang muncul pada A12 dan A20, yaitu asertif, direktif, komisif, ekspresif, dan deklaratif. Hasil analisis kedua korpus tersebut menunjukkan hasil dengan kecenderungan yang sama, yaitu tingginya tuturan asertif sebagai bentuk ekspresi perundungan. Tuturan Asertif mendominasi dengan persentase terbesar sebesar $40 \%$ pada A12 dan sebesar $52 \%$ pada A20 . Data ini membuktikan bahwa ekspresi perundungan siber paling banyak diungkapkan dalam bentuk kalimat pernyataan.

\begin{tabular}{lll}
\multicolumn{2}{c}{ Tabel 11. Tuturan Ilokusi } \\
\hline Tuturan Ilokusi & $\mathbf{A 1 2}$ & $\mathbf{A 2 0}$ \\
\hline asertif & $40 \%$ & $52 \%$ \\
direktif & $28 \%$ & $25 \%$ \\
ekspresif & $23 \%$ & $14 \%$ \\
komisif & $6 \%$ & $5 \%$ \\
deklaratif & $3 \%$ & $3 \%$ \\
\hline
\end{tabular}

Tabel 12. Contoh Tuturan Asertif

\begin{tabular}{l|l}
\hline $\mathbf{A 2 0 . 0 4}$ & dandan lu alim tpi hati lu perek titik \\
$\mathbf{A 2 0 . 7 7}$ & gk pantes lu pake nama mohamad tai lu anak babik lu anyiiiiing emang lu \\
$\mathbf{A 1 2 . 3 5 9}$ & anjing setan lu pake baju mahal, gak akn ketolooong.... \\
\hline
\end{tabular}

Tindak tutur asertif adalah ilokusi di mana penutur terikat pada kebenaran yang diungkapkan, misalnya menyatakan, mengusulkan, membual, mengemukakan pendapat, dan melaporkan(Leech, 2016; Searle, 1969). Berdasarkan hasil analisis data, tuturan perundungan umumnya berbentuk ungkapan pendapat para pelaku perundungan melalui kalimat-kalimat pernyataan berisi ejekan, hinaan, dan umpatan.

Berikut adalah beberapa contoh tuturan direktif pada data A20 dan A12.

Tabel 13. Contoh Tuturan Direktif

\begin{tabular}{l|l}
\hline $\mathbf{A 2 0 . 4 4}$ & woyy... ngaca dong lu, biar kliatan lu itemnya kek ap.. ngaca ngacaaaa pake kaca \\
$\mathbf{A 1 2 . 6 6}$ & $\begin{array}{l}\text { klo gebetan lu banyaaak lu jgn kepedean lu. bkn berati lu cakep anjing. Tny ama } \\
\text { gebetan lu yg cakep lu nya apa dompet bapa lu }\end{array}$ \\
A20.85 & $\begin{array}{l}\text { UAH LAH, NGAKU AJA LAH LU LONTE, ANJING!!!!!! MENJAUH LU DARI GUA } \\
\text { LONTEEEEEEEEEEE DASAR LONTE DASAR LONTE DASAR LONTE }\end{array}$ \\
\hline
\end{tabular}

Contoh tuturan pada tabel di atas menunjukkan bahwa tuturan perundungan juga banyak diungkapkan pelaku dalam bentuk kalimat perintah untuk intropeksi diri (nasehat) dan menjauh dari komunitas.

Tabel 14. Contoh Tuturan Ekspresif

\begin{tabular}{l|l}
\hline $\mathbf{A 1 2 . 2 2}$ & $\begin{array}{l}\text { Surat terbuka untuk juneeet. Hey Juneeet, e nya tiga tapi akhlaknya nol, dasar anak kontol. } \\
\text { Mau ngasih tau aja kalo konten lu ganggu babi. Anjing emang anjing anjing } \\
\text { Dasar anak bangsat lu. Dri spermanya siapa sih heran gw! Kelauan perek, dakjal lu! }\end{array}$ \\
\hline
\end{tabular}


\begin{tabular}{l|l}
\hline A20.371 & Gendut banget si lu, udah gendut jelek lagi eww! Jijik!
\end{tabular}

Tindak tutur ekspresif adalah ilokusi yang berfungsi untuk mengungkapkan sikap psikologis penutur terhadap keadaan yang tersirat dalam ilokusi, misalnya mengucapkan terima kasih, mengucapkan selamat, memberi maaf, mengecam, berbela sungkawa [23].

\section{Simpulan}

Dalam perundungan siber, kata "lu" adalah representasi objek perundungan. Sebagai salah satu kata ganti orang pertama, "lu" merepresentasikan sebuah objek yang lemah dan rendah. Dibandingkan dengan kata "kamu", kata "lu" dianggap lebih mampu mengekspresikan kemarahan, penghinaan, dan materi-materi negatif lainnya dalam tuturan perundungan.

Rentang perbedaan waktu sebanyak delapan tahun belum banyak mengubah ragam bahasa di media sosial dalam hal tuturan perundungan. Berdasarkan temuan, pola tuturan perundungan siber masih memiliki kecenderungan yang sama meski dengan perbedaan jumlah pola tuturan. Pada data tahun 2012 hanya ditemukan 30 pola, sedangkan tahun 2020 ditemukan 36 pola tuturan perundungan siber dengan penggunaan kata "lu".

Satu-satunya perbedaan yang terlihat dari hasil analisis data adalah penggunaan kata yang dipakai tahun 2012 dan di tahun 2020. Apabila ditinjau dari sisi makna dan konteks, kata yang dipakai di kedua tahun tersebut adalah kata yang berbeda, tapi bermakna sama. Kata seperti „"anjay“, ,"modus“, dan „"ambyar" tidak muncul dalam korpus data tahun 2012. Hal tersebut sangat berbeda di tahun 2020, kata-kata tersebut populer dan lazim dipakai para remaja dalam percakapan media sosial. Pada tahun 2012, kata yang populer adalah "anjing", "ngarep", dan "ancur".

Hasil analisis korpus data telah menunjukkan adanya perbedaan dan persamaan tuturan perundungan siber tahun 2012 dan tahun 2020. Temuan tersebut berbeda dengan hasil analisis tindak tutur yang menunjukan, bahwa rentang delapan tahun belum ditemukan perubahan yang signifikan tentang tuturan-tuturan perundungan siber. Hasil analisis tindak tutur menunjukkan, bahwa dalam kurun waktu delapan tahun ini tuturan perundungan siber didominasi oleh tuturan asertif, direktif, dan ekspresif.

Melalui hasil penelitian ini diharapkan ada penelitian lanjutan mengenai tindak tutur perundungan siber dan provokasi dengan korpus yang lebih besar. Melalui penelitian tersebut diharapkan dapat diperoleh deskripsi lengkap dan pemetaan pola-pola tuturan perundungan dan provokasi di media sosial. Lebih lanjut lagi, direkomendasikan kepada pihak-pihak yang berkepentingan dapat memanfaatkan penelitian ini untuk menentukan kata kunci dalam penelitian digital forensik.

\section{Referensi}

[1] E. Swandy. Bahasa Gaul Remaja dalam Media Sosial Facebook. J. Bastra, 2017.

[2] D. Atmawati. Penggunaan Bahasa Pada Media Sosial (the Use of Language in Social Media). Int. Semin. Prasasti III Curr. Res. Linguist., 2016.

[3] KBBI. Kamus Besar Bahasa Indonesia ( KBBI ). Kementerian Pendidikan dan Budaya. 2016.

[4] E. Susanti. Glosarium Kosakata Bahasa Indonesia dalam Ragam Media Sosial. DIALEKTIKA, 
2016.

[5] M. Rifauddin. Fenomena Cyberbullying pada Remaja (Studi Analisis Media Sosial Facebook). Khizanah al-Hikmah J. Ilmu Perpustakaan, Informasi, dan Kearsipan, 2016.

[6] M. Hidajat, A. R. Adam, M. Danaparamita, and S. Suhendrik. Dampak Media Sosial dalam Cyber Bullying. ComTech Comput. Math. Eng. Appl., 2015, doi: 10.21512/comtech.v6i1.2289.

[7] F S Rahayu. Cyberbullying sebagai Dampak Negatif Penggunaan Teknologi Informasi. J. Sist. Inf., 2013, doi: 10.21609/jsi.v8i1.321.

[8] F. Kususmawardhani, H. Khatimah, and D. A. Puspitasari. Kajian Bahan Kebijakan Cyberbullying di Media Sosial pada Pelajar Indonesia. Tidak Diterbitkan, Bogor, 2019.

[9] G. Leech, Principles of Pragmatics. 2016.

[10] Y. Bulu, N. Maemunah, Sulasmini. Faktor-faktor yang Mempengaruhi Perilaku Bullying pada Remaja Awal. Nurs. News (Meriden)., 2019.

[11] B. Tjongjono, H. Gunardi, S. O. Pardede, and T. Wiguna. Perundungan-siber (Cyberbullying) serta Masalah Emosi dan Perilaku pada Pelajar Usia 12-15 Tahun di Jakarta Pusat. Sari Pediatr., 2019, doi: 10.14238/sp20.6.2019.342-8.

[12] P. Miftahul jannah. Intervensi Peningkatan Perilaku Prososial dalam Upaya Menurunkan Perundungan. Pers. Psikol. Indones., 2018, doi: 10.30996/persona.v7i1.1466.

[13] W. F. Sukmaningtyas. Penggunaan Jejaring Sosial pada Perilaku Perundungan Siber Remaja di SMK Negeri 1 Samarinda. eJournal Ilmu Komun., 2017.

[14] A. Fauzan, I. Riadi, and A. Fadlil. Analisis Forensik Digital Pada Line Messenger Untuk Penanganan Cybercrime. 2017.

[16] P. W. Imam Riadi, Sunardi. Investigasi Cyberbullying pada WhatsApp Menggunakan Digital Forensics. Rekayasa Sist. dan Teknol. Inf., 2020.

[17] M. Chen and J. Flowerdew. Introducing data-driven learning to $\mathrm{PhD}$ students for research writing purposes: A territory-wide project in Hong Kong. English Specif. Purp., 2018, doi: 10.1016/j.esp.2017.11.004.

[18] N. Hizbullah, Fazlurrahman, F. Fauziah. Linguistik Korpus dalam Kajian dan Pembelajaran Bahasa Arab di Indonesia. Konf. Nasionan Bhs. Arab II, 2016.

[19] M. S. Al Fajri. Skinny, Slim, dan Thin: Analisis Berbasis Korpus Kata Sifat Identik dan Implikasinya pada Pengajaran Bahasa Inggris. Ranah J. Kaji. Bhs., vol. 8, no. 1, pp. 19-32, 2019, doi: Doi: 10.26499/rnh.v8i1.894.

[20] M. S. Al Fajri. The Construction of Indonesian Muslims and Islam in Australian Newspapers: A Corpus-Assisted Critical Discourse Analysis. Discourse Interact., vol. 13, no. 1, pp. 5-24, 2020, doi: https://doi.org/10.5817/DI2020-1-5.

[21] S. M. Sotillo. Illocutionary acts and functional orientation of SMS texting in SMS social networks Asp. Corpus Linguist. Compil. Annot. Anal., vol. 12, no. 1, pp. 1-14, 2012.

[22] J. L. Austin, How to do things with words. Cambridge: Harvard University Press, 1962.

[23] J. R. Searle. Speech acts: An essay in the philosophy of language. Cambridge: Cambridge University Press., 1969.

[24] E. Dresner and SC Herring. Functions of the nonverbal in CMC: Emoticons and illocutionary force. Commun. Theory, 2010, doi: 10.1111/j.1468-2885.2010.01362.x.

[25] J. T. Nastri, J., Pena, J. \& Hancock. The construction of away messages: A speech act analysis," J. Comput. Commun., vol. 11, no. 4, pp. 205-232, 2006.

[26] J. R. Searle and D. Vanderveken. Speech Acts and Illocutionary Logic. in Logic, Thought and Action, 1985. 